\title{
Firm Value and External Financing Needs
}

\author{
Aykut Karakaya $^{1}$, Ayten Turan Kurtaran ${ }^{2} \&$ Ahmet Kurtaran $^{3}$ \\ ${ }^{1}$ Department of Business Administration, Recep Tayyip Erdoğan University, Rize, Turkey \\ ${ }^{2}$ Faculty of Health Sciences, Karadeniz Technical University, Trabzon, Turkey \\ ${ }^{3}$ Department of Business Administration, Karadeniz Technical University, Trabzon, Turkey \\ Correspondence: Ahmet Kurtaran, Department of Business Administration, Karadeniz Technical University, \\ Trabzon, Turkey. Tel: 90-462-377-8779. E-mail: kurtaran@ktu.edu.tr
}

Received: March 31, 2017

Accepted: April 26, 2017

Online Published: May 15, 2017

doi:10.5539/ijef.v9n6p69

URL: https://doi.org/10.5539/ijef.v9n6p69

\begin{abstract}
The purpose of this paper is to examine effects on firm value of external financing needs and BIST 100 index to firms listed in the index of Istanbul Stock Exchange manufacturing industry by the panel data analysis methods in the period of 2008-2012.

As a result of dynamic panel data analysis, it has be found to increase value of firms by previous term value of firm, being the BIST 100 index, the external financing needs, the financial leverage ratio, firm size and profitability. It was observed that manufacturing firms in Turkey are firms having growth potential, profitable at low rate, whereas financial risk of them is high.

It has been found that firms benefit from shorts term debt market being lower borrowing cost and risk because long term debt market hasn't developed in Turkey leads to positive relationship between external financing needs and firm value. Additionally, It is determined that value of firms included in the index is higher from without because firms are necessary providing certain conditions to take part in the BIST 100.
\end{abstract}

Keywords: firm value, external financing needs, panel data analysis, BIST100, Turkey stock market

\section{Introduction}

Under developing and changing economic conditions, companies that wish to continue operating confront with an increasingly competitive environment and take a variety financial decisions to be able to survive, grow and make profit. In this financial decisions, selection and provision of financial sources as required by company's growth strategy is vital for the company. Firms enter into a rapid growth process due to psychological effects arising from both economical and competition. The firms not keeping up to this process can force and can come up with activities to a halt in the face of growing firms.

Growth of firms can be handled from different angles. For example, increase in sales, total assets and profitability, the increase in the number of employees, expansion of firms through mergers or acquisitions, increase the number of branches, product diversification and development are the factors that lead to growth. The increase in sales has often been used as a measure of growth in studies since it is relatively easy to detect.

Firms that finance themselves from temporary gains are less affected, while firms whose financing needs exceed their internal resources can be severely limited. To measure whether access to financial markets impacts the ability of a firm to use growth options, it is necessary to identify firms with external financing needs and examine whether the achieved growth depends on the development of financial markets. (Demirgüç-Kunt \& Maksimovic, 1998, p. 2109).

Growth and external financing needs are two interrelated concepts. If other conditions are considered fixed, external financing needs will increase to the extent that growth rate of a firm's sales or assets is higher. There is a linear relationship between external financing needs and growth (Dağl1, 2007, p. 130).

The internal cash flows associated with firms' investment opportunities are one of the key elements that determine the need for external financing. But the cash flows and the optimal level of investment are not entirely internal, as they are influenced by many factors such as the strategies of other companies, legal process, and economic conditions. These factors are not determined by the internal dynamics of firms. Therefore, firms do not 
have full control over environmental factors.

Question of this research is that how is the relationship between firm value and external financing needs. In the study, the answer of this question will be searched.

Therefore, the purpose of this paper has been investigated effects on firm value of external financing needs and BIST 100 index to firms listed in the index of Istanbul Stock Exchange manufacturing industry in the period of 2008-2012.

Although this topic investigated for many stock markets in the literature, It hasn't found any studies examining effects on firm value of external financing needs in Turkey. Thus, it is expected to contribute to the literature of this study.

It was found that manufacturing firms in Turkey are firms having growth potential and profitable by rate about 5\% of net sales. Also, it was determined that because manufacturing firms in Turkey have provided by borrowing more than half of financial resources, financial risk of their is higher.

In Turkey, it was determined while firms having high value are high leverage proportion, total assets is low. In addition to, it has been found that large-scale firms have higher profitability and use less debt resource.

As a result of the study, it has been found to increase value of firms by previous term value of firm, being the BIST 100 index, the external financing needs, the financial leverage ratio, firm size and profitability.

The remainder of this article is organized as follows. In section II, we review the related literature and develop research hypotheses. Section III describes the research design, including data sources, research period, sampling standard and construction of the empirical model. Section IV presents our empirical findings. Section V concludes this article.

\section{Previous Research and Hypothesis Development}

When encountered with potentially profitable opportunities for growth, firms will often find themselves faced with the choice of either using their internal resources to finance any proposed ventures, or seeking to raise such funds from external resources.

Although not observed a study examining the relationship between external financing needs and growth in Turkey, there are studies on this topic in other markets. However, in these studies is seen mostly discussed the growth of firms and remained limited number of the studies examining as direct the relationship between external financing needs and firm value. In this section, we are briefly mentioned some of these studies.

Higgins (1977) suggests a sustainable growth rate approach. With this approach, it is desirable to determine the maximum growth rate in company sales that will prevent the depletion of financial resources. Higgins assumed that when the firm wants to maintain its capital structure, retained earning generates additional equity and the firm borrows sufficient funds. If other things are being equal, sustainable growth rate in sales will rise if the firm can improve its assets utilization by reducing the assets required to support existing sales. This might be achieved by liquidating redundant fixed assets or, if possible, by reducing current assets while maintaining sales. Platt et al. (1995) is developed sustainable growth rate formula telling firms operating in financial markets whether they need to raise new funding sources to achieve a sales growth above the sustainable growth rate. Langberg (2008) investigated what they were paying attention to when financing a growing company's investments. It explored how these firms use debt and equity financing methods to assess future investment opportunities. As a result of the research, it was determined that the debt is better for lowering the inspection cost, and it is best because the partial capital ownership for the investors is more appropriate and reduces the need to be tested in the presence of valuable growth opportunities. Hughes et al. (2009) examined the relation between implied cost of capital and expected returns under an assumption that expected returns are stochastic. They show that the implied cost of equity capital is not equal to the expected return and is a function of expected return on equity, leverage, growth, beta volatility and cash flow volatility.

Ghosh (2008) examined the association between corporate leverage and profitability using firm-level data on manufacturing sector in India for 1995-2004. This study indicated that the debt equity ratios of firms increase, in other words they use more debt than their equity. And the ratio of firms' profitability and cash flows to assets is decreasing. In addition to these results, the increase in leverage has marginally influenced the profitability of companies participating in international debt markets relative to other firms. Mckeon (1969) have examined the structure of corporate external financing during the postwar period through 1968 in the United States. In conclusion, he has determined commercial paper financing has expanded enormously. In addition, firms began not to use alternative financing with stocks, bank loans were much more volatile than other corporate external 
financing, and bond financing reached about half of the total in each of the five-year periods since the end of the war.

Demirgüç-Kunt and Maksimovic (1996) revealed that in developed stock markets, further development leads to a substitution of equity for debt financing. Demirgüç-Kunt and Maksimovic (1998) investigated that use of long-term debt or external equity to fund growth and developed a financial planning model to obtain the maximum growth rate that each firm in thirty-country sample could attain without access to long-term financing. They found that in countries whose legal systems score high on an efficiency index, a greater proportion of firms use long-term external financing. Almeida and Wolfenzon (2005) developed an equilibrium model to understand how the efficiency of capital allocation depends on outside investor protection and firms' external financing needs. Especially in this study, it is analyzed how external financing needs of firms affects the efficiency of capital allocation. Almeida and Campello (2010) were proposed to provide evidence on the relation between internal funds and external financing for constrained and unconstrained firms. According to the authors, there is ample evidence pointed to a negative relation between internal funds and the demand for external funds. This relation has been interpreted as evidence supporting the pecking order theory. In addition to, they argued that the greater complementarity between internal funds and external financing for constrained firms was a consequence of the interdependence of their financing and investment decisions. Rashid (2014) examined how firm specific and macroeconomic risks affect the external financing decisions of UK manufacturing firms. The results revealed that firms are less likely to use capital markets when macroeconomic risks are high, whereas, they tend to rely more on external financing when firm specific risk is high.

Variables determined benefiting from research in the literature section are BIST 100 index, external financing needs, leverage, size and profitability. These variables are described in detail in the section data and methodology. The relationship between each variables and firm value have examined considering studies in the literature in the following section.

\subsection{BIST 100 Index and Firm Value}

In the literature, findings concerning companies listed in the index have higher value were obtained. Shleifer (1986) found that a company' stock price rises significantly on the news that it will be added to the S\&P 500, and argues that this value increase is permanent. Howewer, Jain(1987) and Dhillon and Johnson (1991) replicate Shleifer's (1986) finding rejecting a complete reversal. They suggested that inclusion in the index amounts to "certification of quality", and that this is the ultimate cause of the value increase. Wurgler and Zhuravskaya (2000) found that the abnormal returns associated with inclusion in the S\&P 500 are larger for stocks that are less likely to have close substitutes. Kaul et. al. (2000) indicated that inclusion in the index causes an immediate share price increases. Lynch and Mendenhall (1996) found a significantly positive announcement effect for firms added to S\&P 500 index. Morck and Yang (2001) found that membership in the S\&P 500 index is associated with significantly higher valuation, measured by average Tobin's q ratios, even after controlling for standard variables known to affect q ratios. At the same time, they demonstrated that inclusion within the S\&P 500 has a positive impact on the value of a firm, and that this impact was greatly increased during the 1990s. Therefore, we develop the hypothesis as follows:

\section{H1: There is a positive relationship between being within the BIST 100 index and firm value.}

\subsection{External Financing Needs and Firm Value}

According to the recent studies in the literature, there is a negative relationship between the profitability of the firm and the need for external financing. Leary and Roberts (2005) find that firms that have high cash flows or high cash balances are less likely to issue both debt and equity. Other studies that determine a negative relationship between profitability and external financing need belong to Hennessy and Whited (2005) and Lewellen and Lewellen (2006). Strebulaev (2007) suggested that the negative relation between profitability and external financing could be due to the presence of adjustment costs. Almeida and Campello (2010) findings do not support studies that are usually associated with standard pecking order tests. Because the negative relation between profits and external financing is concentrated among financially unconstrained firms, it is unlikely that asymetric information is the driver of this negative relation. Chen et al. (2010) found that external financing needs appeared to strengthen the influence of the quality of corporate governance practices on firm value. Almeida and Wolfenzon (2005) argued that where there are certain deficiencies in firm performance the use of external financing has obvious benefits. They suggested that external financing needs can be seen as a mechanism affecting the efficient allocation of capital. Demirgüç-Kunt and Maksimovic (1998) investigated how differences in legal and financial systems affect firms' use of external financing to fund growth. They revealed that developed institutions not only permit firms to fund growth externally, but also may indirectly increase 
dependence on external financing by reducing firms'profits. Anderson, Mansi and Reeb (2004) suggested that both the size and independence of the board have significant associations with lower costs of debt financing. According to their findings, firms with better governance structure are likely to have lower costs of equity and/or debt. Therefore, we develop the hypothesis as follows:

\section{H2: There is a negative relationship between external financing needs and firm value.}

\subsection{Leverage and Firm Value}

When the review of the literature, there are different opinions related to impact of leverage on firm performance. Demirgüç-Kunt and Maksimovic (1996) found that in general there is a significant positive relationship between bank development and leverage and a negative but insignificant relationship between stock market development and leverage. Nissim and Penman (2003) investigated the implications of the financing leverage and operating liability leverage for profitability and equity value. They found that operating and financing liabilities implied different profitability and were priced differently. Cohen and Lys (2006) found that to capture stock returns following net equity and debt financing activities have a strong negative relation with leverage. Muller et al. (1984) examined that risk-return characteristics of the portfolios are compared with performance as measured by fundamentals data regarding earnings, dividends, firm size, leverage, and return on equity. They found that relationships between quality (firm risk) and leverage are discernible only at the extremes. In other words, the relationship between quality and leverage is not uniform except at the extremes, on average, the lowest quality firms are more highly leveraged than the highest quality firms. For the middle quality groups, leverage is not a differentiating characteristic. Like previous studies, Kasseeah (2008) found a negative and significant relationship between leverage and profitability of Chinese listed manufacturing firms, which indicates that Chinese firms rely on internal finance. These finding are in accordance with the results obtained by Chen (2004) and Huang and Song (2006) and confirm the finding that Chinese firms always prefer to use internal finance before debt in their financing. Jensen and Meckling (1976) argue that highly levered firms may have an incentive to take on projects that have negative expected net present values and are risky, thereby harming creditors. Titman (1984) argues that as high leverage increases the probability of financial distress sufficiently, the firm will enter into contracts that it may be unable to execute. Maksimovic (1988) and Maksimovic and Titman (1991) argue that leverage increases the firm's incentive to renege on value-enhancing implicit contracts with rival firms or with customers. Chen et. al. (2010) found that leverage has a significantly negative association with firm performance. Therefore, we develop the hypothesis as follows:

\section{H3: There is a negative relationship between leverage and firm value.}

\subsection{Size and Firm Value}

In the majority of studies failed to reach a consensus on the measure of firm size. It can be measured through total assets, total sales, and employment or through total profits. We have chosen the log natural of total assets to the reason of which is mainly adopted by other researches as well.

According to Glancey (1998) when larger firms take advantage of the scale economies, a positive relationship is expected between profitability and firm size. Singh and Whittington (1975) used UK data and depicted a positive relationship between firm size and growth. Regarding firm size Rashid (2014) observed a significant and positive coefficient. In other words, an increase in firm size may lead to lower default risk as a percentage of total assets or total debt. Hence, larger firms have tendency to have higher target leverage. Langberg (2008) predicted that high growth firms allocate a higher fraction of firm equity to outside investors and finance a larger portion of investment with external equity, relative to debt. In particular, young firms rely more on external equity financing, relative to debt, and issue new equity more frequently, relative to mature firms. Chen et. al. (2010) found that size has a negative relationship with firm value, which is consistent with Jang and Park (2011). Therefore, we develop the hypothesis as follows:

\section{H4: There is a positive relationship between size and firm value.}

\subsection{Profitability and Firm Value}

In most of the previous studies was found that profitability has positive impact on the firm performance. Demirgüç-Kunt and Maksimovic (1998) explored that less profitable firms are more likely to grow at rates that require them to obtain long-term credit or equity. In twenty-one of the thirty cases the coefficients are negative. Only in the case of Zimbabwe are more profitable firms more likely to require external financing. Coad (2007) found the positive relationship between profitability and growth in his research on the sample drawn from French manufacturing firms. Papadogonas (2005) analyzed the financial performance of manufacturing firms in Greece in during 1995-1999 to determine factors related to firm profitability. According to the results, 
profitability is affected by sales growth, investment in fixed assets, managerial efficiency, size, and debt structure. Asimakopoulous et al. (2009) determined that large firms have high profit. So, they found positive relationship of size and profitability. Kouser et al. (2012) found that profitability has strong positive relationship with the growth of the firm. Langberg (2008) predicted that profitability is non-monotonic over the firm's growth cycle, increasing at first when the firm is young but decreasing afterwards. Interestingly, the equilibrium relation between leverage and profitability for mature firms is consistent with the well-known empirical regularity that better performing firms (e.g., higher profit) have lower leverage ratios, while the equilibrium relation is reversed for young firms. Rashid (2014) determined that profitable firms are more likely to choose debt rather than equity while financing their capital needs from external resources. This findings is in line with the target adjustment hypothesis of the static trade-off theory, which states that the more profitable the firm, the more likely the firm will issue debt versus equity. Therefore, we develop the hypothesis as follows:

H5: There is a positive relationship between profitability and firm value.

\section{Data and Methodology}

In this study, the effect on firm value of EFN of firms listed Borsa Istanbul Sinai Index over the period 2008-2012 were examined with panel data analysis method. The analysis was performed with annual data. The data of firms were obtained from public information on web site of Public Disclosure Platform and were compiled by the researchers. The data set of the study consists of 136 firms each year and a total of 680 observations. Variables of the study were designated under cover of studies in the relevant literature. The variables in question are presented in Table 1.

Table 1. The variables used in the study

\begin{tabular}{lll}
\hline Variables & Code & Descriptions \\
\hline $\begin{array}{l}\text { Dependent Variable } \\
\text { Firm Value } \\
\text { Independent Variables }\end{array}$ & Tobin's Q & (Total Debt + Market Value of Stock - Equity) / Total Assets \\
BIST 100 Index & & \\
External Financing Needs & BIST100 & If the firm is listed BIST 100 Index =“1"; otherwise= "0" \\
Leverage rate & EFN & Real Growth Rate of Assets-Sustainable Growth Rate \\
Size & LEV & Total Debt / Total Assets \\
Profitability & SIZE & Real Total Assets by 2007 Prices \\
\hline & EBITS & EBIT/Net Sales \\
\hline
\end{tabular}

The most primary method of panel data analysis is Pooled Least Squared (PLS). But it cannot be obtained consistent estimates with PLS analysis if there is a relationship between error terms and independent variables of panel data set. In such a case, using PLS analysis is objectionable. In addition, because of unit and time unobservable effects which are in panel data set, PLS analysis take no account of autocorrelation within themselves of errors (Wooldrige, 2002, p. 256). In order to overcome these disadvantages, special estimators have been developed for panel data analysis. These estimators can be divided into two groups, namely static and dynamic.

The most widely used of static panel data analysis models are Fixed Effects-FE and Random Effects-RE models. Besides, Generalized Method of Moments-GMM estimators come to the forefront within dynamic panel data analysis models.

The changes occurred by time or units in FE models that means there is a fixed value of each cross-sectional unit generate variations on fixed parameter. Moreover, these changes transform the parameters which are estimated together with slope parameters (Hsiao, 2003, p. 30). It is assumed that unit effects or difference between units in FE model. It is used generally Least Squared Dummy Variable-LSDV and within groups fixed effect method in estimation of FE models (Arellano, 2003, pp. 11-46). It is preferred within groups instead of LSDV in this study because of loss of degrees of freedom arising from number of units.

The difference between units becomes random not fixed when the sample is selected as random. Besides, random intervals are estimated with RE model. Because unit effect is not fixed in RE model it takes part within error term not constant term. Thus error term is divided into two parts indicating unit and residual error. The size of this unit error reveals the importance of unit effect (Baltagi, 2005, p. 14). In this study, Generalized Least Squared-GLS estimator is used to estimate the RE model since its calculation is easy.

A rule regarding which of the FE and RE models will be used is not clear (Öztürk, 2011, p. 37). The aim to be 
desired to achieve is effective generally in decision related to which one is preferred. Additionally, this is dependent on sample studied. If the data is obtained from closed sample and consist of a specific group of people or a specific region the FE model would be more appropriate. If the data is obtained from a big population via random sample, in that case, using RE model may be a better decision (Swamy \& Mehta, 1977, pp. 890-898). Except for this intuitive approach, there are developed different statistical tests for decide that which of FE or RE models will be applied. The most popular of them is Hausman (1978) test.

Dynamic panel data analysis base on Generalized Method of Moments-GMM that firstly developed by Hansen (1982) in econometric literature. Anderson and Hsiao (1981) and Anderson and Hsiao (1982) has been adapted GMM approach to panel model. Then this method has been developed by Arellano and Bond (1991), Arellano and Bover (1995) and Blundell and Bond (1998). Additionally, panel data is located in literature as GMM and System Generalized Method of Moments-SGMM called scholar names.

In GMM prediction approach, primarily, first difference of the model is taken and the difference is transformed by using instrumental variable matrix of the model. Then, the transformed model is predicted by Generalized Least Squared-GLS. The first difference transformation is weak in the panel data, the data set of which is unbalanced or the number of unit is less than the time. In this case, SGMM using orthogonal deviations is used. Thus, it is obtained efficient instrumental variable estimator with SGMM (Baltagi, 2005, p. 148). In SGMM, it is taken the difference from average of future values of variables instead of taking the difference between the current period and previous period in GMM. Thus, data loss arising from first differences approach is minimized (Blundell \& Bond, 2000).

Therefore, the SGMM estimation method is preferred in determining the linear relationship between variables in the panel data sets where the unit is large. There are also two step estimators of GMM and SGMM. Where the independent variables are endogenous, the findings from the two-step estimates are more consistent and unbiased.

Because the number of unit is bigger than the time in data set of this study, estimations have been obtained from two steps SGMM estimation method suggested by Arellano and Bover (1995) and Blundell and Bond (1998). Furthermore, it has been used robust estimates of standard errors of Windmeijer (2005) for getting standard errors have no deviation in estimations.

The equations generated in this study and the variables existing as simultaneous and lagged in these equations are shown below (follows).

In this study, the effect on firm value of manufacturing firms of external financing needs has been estimated with both dynamic and static panel data analysis approaches. The given relationship is represented by the following equations. The first of the equations (1) used for this demonstrate static FE model while the second (2) demonstrate dynamic GMM model.

$$
\begin{gathered}
T Q_{i t}=\beta_{0}+\beta_{1} B I S T 100_{i t}+\beta_{2} E F N_{i t}+\beta_{3} L E V_{i t}+\beta_{4} L S I Z E_{i t}+\beta_{5} E B I T S_{i t}+\mathrm{u}_{i}+v_{i t} \\
T Q_{i t}=\beta_{0}+\beta_{1} T Q_{i t-1}+\beta_{2} B_{S I S T 100_{i t}}+\beta_{3} E F N_{i t}+\beta_{4} L E V_{i t}+\beta_{5} L S I Z E_{i t}+\beta_{6} E B I T S_{i t}+\varepsilon_{i t}
\end{gathered}
$$

where $t$ and $i$ denote time and firm respectively. In first equation, $u_{i}$ is fixed effect of firm and $v_{i t}$ is idiosyncratic error term. In the second question, $T Q_{i t-1}$ denote one period lag of dependent variable adding a dynamic feature on model and $\varepsilon_{i t}$ is error term. where $T Q_{i t}$ is firm value, $B I S T 100_{i t}$ is dummy variable that is 1 if the firm is listed Borsa Istanbul 100 index otherwise $0, E F N_{i t}$ denote external financing need, $L E V_{i t}$ denote financial leverage, $L S I Z E_{i t}$ denote size and EBITS $i t$ denote operating return margin.

\section{Results}

The findings of analysis are viewed on two sections as descriptive statistics and findings of panel data analysis. In descriptive statistics, the results obtained from the sample dataset are presented. In the panel data analysis findings, the results of the analysis of the firm value model of the research with the help of different estimators are mentioned.

\subsection{Descriptive Statistics}

Descriptive statistics calculated for the purpose of establishing the situation of the firms examined in the study are examined under two headings: general characteristics of the sample and relationship between variables.

\subsubsection{General Features of Sample}

General features of the variables used this study are reported in Table 2. As can be seen in Table 2, average of TQ value that is indicator of firm value is 1.40 , average of profitability is $4.76 \%$, average of financial leverage is 
$59.7 \%$, average of external financing need is $8.66 \%$ and average of real asset size is 690 Million TL. The value of average TQ shows firms have growth potential in market and are emerging. In terms of profitability, the value of average EBITS point out that the firms make approximately $5 \%$ operating profit on sales. In other words, the firms finish by profit for the period in terms of though low.

Table 2. Basic statistics on the variables

\begin{tabular}{lcccc}
\hline Variables & Minimum & Maximum & Average & Standard Deviation \\
\hline TQ & 0.215 & 12.837 & 1.403 & 1.209 \\
EFN $(\%)$ & -164.407 & 6044.178 & 8.661 & 231.879 \\
LEV $(\%)$ & 2.4 & 1256.3 & 59.7 & 0.915 \\
SIZE (TL) & $5,300,340$ & $11,700,124,639$ & $689,726,535$ & $1,553,759,600$ \\
EBITS (\%) & -180.576 & 824.489 & 4.761 & 36.751 \\
\hline
\end{tabular}

Financial leverage indicate that the firms provide more than half of financial sources with borrowing, namely, the firms put up with high financial risk. Another confirmatory of this finding is the fact that manufacturing firms have positive external financing need of the average rate of $8.66 \%$. In brief, it said that the examined firms have growth potential, profitable even if it is low rate, but however, whose financial risks are high since leverage and external financing need are high.

Table 3 indicates number of firms existing in BIST 100 index and EFN value of positive and negative. Accordingly, while there is no significance change in the number of listed firms in BIST 100 index, there is in EFN variable. The change in EFN variable began in 2009 and continued until 2012. Whereas the number of firms with negative and positive EFN value is close to each other, number of which EFN value is negative has increased significantly in the forthcoming years. In other words, change took place to the detriment of those have positive EFN and in countenance of those have negative EFN.

Table 3. BIST 100 \& EFN variables by years

\begin{tabular}{lcccccc}
\hline Years & BIST 100 & Non BIST 100 & Total & EFN+ & EFN- & Total \\
\hline 2008 & 34 & 102 & 136 & 69 & 67 & $\mathbf{1 3 6}$ \\
2009 & 35 & 101 & 136 & 39 & 97 & $\mathbf{1 3 6}$ \\
2010 & 33 & 103 & 136 & 52 & 84 & $\mathbf{1 3 6}$ \\
2011 & 30 & 106 & 136 & 49 & 87 & $\mathbf{1 3 6}$ \\
2012 & 35 & 101 & 136 & 42 & 94 & $\mathbf{1 3 6}$ \\
\hline \multicolumn{1}{c}{ Grand Total } & $\mathbf{1 6 7}$ & $\mathbf{5 1 3}$ & $\mathbf{6 8 0}$ & $\mathbf{2 5 1}$ & $\mathbf{4 2 9}$ & $\mathbf{6 8 0}$ \\
\hline
\end{tabular}

In other word, the number of firms needed external financing decreases while the number of firms which have surplus financing increases. It can be said that effect of global financial crisis arisen in fourth quarter of 2008 year played a big role in this transformation. If the crisis had only domestic origin the firms could overcome these difficulties because they had previously been experienced from domestic origin 2001 financial crisis. The firms had gone to foreign markets on then crisis. However, the firms could not overcome this effect due to the recession in both production and consumption factors market in the environment of global financial crisis.

\subsubsection{Relationships Between Variables}

Table 4 shows the Pearson correlation coefficient revealed a relationship between two variables. Pearson correlation coefficient shows the level of the linear relationship between variables. The correlation coefficient of TQ which is the dependent variable of study with LEV and SIZE independent variables is significant statistically at $1 \%$ level. It is said that the firm value and leverage are move in the same direction whereas the size is moving in the opposite direction. According to correlation analysis the firms whose value is advanced have high leverage while their total assets are small. When examined to the bilateral relations between the independent variables it is not significant statistically only the correlation of external financing needs with the variable. The correlations between profitability, leverage and size are statistically significant. With respect to direction of the relationship between these variables, there is a positive relationship between size and profitability whereas there is a negative relationship between profitability and size with leverage. This finding demonstrates larger firms have higher profitability and use less debt (liabilities). 
Table 4. The Correlation coefficients of the variables

\begin{tabular}{lllll}
\hline & TQ & EBIT & LEV & EFN \\
\hline TQ & 1 & & & \\
EBIT & -0.046 & 1 & & \\
LEV & $0.643^{* * *}$ & $-0.111^{* * *}$ & 1 & \\
EFN & 0.042 & -0.025 & 0.009 & 1 \\
LSIZE & $-0.169^{* * *}$ & $0.175^{* * *}$ & $-0.227^{* * *}$ & 0.003 \\
\hline
\end{tabular}

Note. $*$, **, and $* * *$ indicate statistical significance of $0.10,0.05$ and 0.01 respectively.

In addition to the above expression, multicollinearity arisen from high relationship between independent variables in multiple regression analysis may arise. This problem endangers consistency of the estimate. Therefore, it should detecting multicollinearity problem and eliminating if it exists. The most commonly used methods for the detection of multiple linear connection problems are correlation, variance inflation factor and tolerance indicators. (It is countable that correlation, variance inflation factor and tolerance indicators on between the most commonly used methods for the detection of multiple linear connection problems). Looking at the correlation coefficients on between independent variables in Table 4, it can be seen that multicollinearity problem does not exist.

\subsection{The Findings of Panel Data Analysis}

In this section, the estimation findings obtained from PLS, FE, RE and two steps System Generalized Method of Moments suggested by Arellano and Bover (1995) and Blundell and Bond (1998) is presented. The results obtained from these estimators are summarized in Table 4. Consistency of PLS, FE, RE and two steps SGMM estimator are presented in Table 5 and xplanations are given below on the subject.

In PLS estimator, initially, it has been done the White (1980) test for determining whether the residual variance is constant and determined that there is no heteroscedasticity, in other words, it has been determined that there is constant variance $\left(X^{2}=13.80\right.$ and $\left.\mathrm{p}=0.795\right)$. Secondly, Wooldrige (2002) autocorrelation test has been made and it has been determined that there is the first order autocorrelation $(\mathrm{F}=7.358$ and $\mathrm{p}=0.008)$. Hence, the estimator developed by Arrelano (1987), Froot (1989) and Roger (1993) is implemented to the data set having constant variance and autocorrelation. According to the test results, estimated PLS model is significantly in general $(\mathrm{F}=56.21$ ve $\mathrm{p}=0.000)$. According to this estimator, clarification level of firm performance is $41 \%$ with performance model.

In FE estimation model, firstly, it has been made the Modified Wald test for determining whether the heteroscedasticity exist and determined that there is heteroscedasticity $\left(X^{2}=1600000\right.$ ve $\left.p=0.000\right)$ (Green, 2003). Secondly, autocorrelation test has been made with Baltagi-Wu(1999) the Locally Best Invariant (LBI) Test. It is decided that there is no autocorrelation because the test value is quite close to 2 (Baltagi-Wu LBI $=1.602$ ). Subsequently, the dependence of the unit have been tried to reveal with Breush-Pagan Lagrange Multiplier Test and found that the correlation between units exist namely, it has been found to be dependent of the units (X2=18325.179 and $\mathrm{p}=0.000$ ). Afterwards, it has been performed Parks (1967) and Kmenta (1986) estimator because of existence of heteroscedasticity and correlation between units in the data set. The FE model is significant generally $(\mathrm{F}=64.92$ and $\mathrm{p}=0.000)$. Ultimately, approximately $40 \%$ of firm performance by $\mathrm{FE}$ estimator is explained.

The heteroscedasticity for RE estimator is measured with Levene (1960), Brown and Forsythe (1974) Test and it has been reached that variance of units is fluxional (W0: 12.2795, $\mathrm{p}=0.000$; W50 $=3.4263, \mathrm{p}=0.000$ and $\mathrm{W} 10=12.2795, \mathrm{p}=0.000)$. then, it has made autocorrelation test with Baltagi-Wu(1999) the Locally Best Invariant (LBI) Test and decided that there is no autocorrelation because the test value is quite close to 2 (Baltagi-Wu LBI = 1.602). In the later stages, Peseran (2004) Test is implemented for dependence of units. According to the results obtained the test, it is found that the correlation between units exist, namely, it has been seen that the units are dependent each other $(\mathrm{CD}=95.172$ and $\mathrm{p}=0.000)$. Afterwards, it has been performed Parks (1967) and Kmenta (1986) estimator because of existence of heteroscedasticity and correlation between units in the data set. The RE model which has been estimated is significant generally (Wald $=427.82$ and $\mathrm{p}=0.000$ ). As a result of analysis, the explaining level of firm performance by FE estimator is more than the other estimators with approximately $44 \%$ level.

As results of the tests in Table 5, estimator should be selected is RE from among PLS, FE ve RE estimators (F Test $=5.78$ and $\mathrm{p}=0.000$; Hausman Test $=4.29$ and $\mathrm{p}>0.05$ ). Additionally, it has been founded that the correlation 
between independent variables and unit effects is low $(-0,179)$ in FE model. Thereby, the unit effects are random, not constant and significant. Therefore, it is understood that it is more appropriate the fact that the estimations and interpretations should be done according to RE estimation approach. In other words, PLS and FE models PLS model should not be preferred for performance.

The $\rho$ which is rate of variance of unit effect error $\sigma_{u}$ to variance of combined error $\sigma_{e}$ in RE estimation model is approximately 50\%. This 50\% difference is importance level of heterogeneous of firms or unit effect. In other words, it is importance of differences in decisions taken by the firm management.

According to the findings obtained from two steps system GMM estimator which is a dynamic panel data analysis, the results of Wald Test for the overall significance of the model indicate that the model is significant as a whole (Wald $=2712.93$ and $\mathrm{p}=0.000$ ). As for that the model, the first order autocorrelation test indicates that Arellano and Bond autocorrelation (AR1) test is significant. But, the second order autocorrelation (AR2) test is not significant. Thus, the absence condition of second order autocorrelation required for suitability of the model is provided. Afterwards, the Sargan Test for validity of instrumental variable obtained from the models is not significant. This test indicates that the instrumental variables used in estimating of performance model made by the SGMM are valid and the model is appropriate. Thus, it has been determined that dynamic performance model provides the conditions related to the overall significance, autocorrelation and instrumental variables regression.

The results of the non-dynamic RE and dynamic two-steps SGMM estimators in Table 5 are investigated in terms of the effects of the independent variables. The effect on firm performance of independent variables except for operating profit margin (EBIT) in RE estimator is statistically significant. Aspect of the effect is negative only in terms of SIZE variable whereas it is positive in BIST 100, EFN and LEV variables. Consequently, it can be seen that external financing needs, financial leverage and existence of firm in BIST 100 index enhance the firm's performance. Contrary to this (In contrast), scale of firm reduce performance of firm.

Additionally, the results obtained from dynamic panel analysis should be presented since static analysis results do not enough for making more reliable determination and comment. Mostly, the previous performance of firms is one of the important determinants of subsequent performance. This situation is based on firm policies such as mission, vision, strategy and continuity of management.

Tablo 5. Performance model analysis results

\begin{tabular}{|c|c|c|c|c|}
\hline Variables & PLS & FE & RE & SGMM \\
\hline Constant & $1.6782^{* * * *}$ & $5.4310^{* *}$ & $2.2571^{* * * *}$ & \\
\hline $\mathbf{T} \mathbf{Q}_{\mathrm{t}-1}$ & & & & $0.7768^{* * *}$ \\
\hline BIST 100 & 0.1170 & $0.3367^{* * *}$ & $0.2617^{* *}$ & $0.1184^{*}$ \\
\hline $\mathbf{E F N}_{t}$ & $0.0002^{* * *}$ & $0.0002^{* * * *}$ & $0.0002^{* * *}$ & $0.0036^{* *}$ \\
\hline $\mathbf{L E V}_{t}$ & $0.8429^{* * *}$ & $0.8311^{* * *}$ & $0.8517^{* * * *}$ & $0.4664^{* * *}$ \\
\hline LOGRSIZE & $-0.0426^{*}$ & $-0.2414^{*}$ & $-0.0750^{* *}$ & $0.0061^{* * *}$ \\
\hline EBIT $_{t}$ & 0.0011 & 0.0006 & 0.0007 & $0.014^{* * *}$ \\
\hline $\mathbf{R}^{2}$ & 0.4176 & 0.3942 & 0.4419 & \\
\hline F Statistic & $56.21^{* * *}$ & $64.92^{* * *}$ & & \\
\hline Wald Statistic & & & $427.82^{* * *}$ & $2712.93^{* * *}$ \\
\hline F Test & & $5.78^{* * * *}$ & & \\
\hline Hausman Test & & & 4.29 & \\
\hline$\sigma_{u}$ & & 0.7593 & 0.6561 & \\
\hline$\sigma_{e}$ & & 0.6622 & 0.6622 & \\
\hline$\rho$ & & 0.5342 & 0.4977 & \\
\hline AR1 Test & & & & $-2.46^{* *}$ \\
\hline AR2 Test & & & & 1.63 \\
\hline Sargan Test & & & & 18.81 \\
\hline
\end{tabular}

Note. *,**, and *** indicate statistical significance of $0.10,0.05$ and 0.01 respectively.

The findings of two-steps SGMM in the light of these realities can be summarized as follows:

The effect of all of the independent variables and one period lag of dependent variable on firm value is statistically significant. The direction of effect on firm value is positive for all variables. It can be seen that the previous period firm value, BIST 100 index, external financing needs, financial leverage, size of firm and profitability increase firm value. 
The fact that firm value of previous period (TQt-1) increase firm value of current period indicate that firm values positively interact with each other. Namely, it has been found the firms having high (low) value have more potential to be a high (low) value in the future.

Furthermore, it has been found a positive relationship between firm value and BIST 100 index, and is supported hypothesis 1. Thus, it has been determined that the firms listed in BIST 100 index have a higher firm value than the others. Similar results were found for S\&P 500 index in the studies done by Shleifer (1986), Jain (1987), Dhillon and Johnson (1991), Lynch and Mendelhall (1996), Wurgler and Zhuravskaya (2000), Kaul et. al. (2000) and Morck and Yang (2001). This finding reached for Turkey also support common results in the literature. Firms in Turkey are required to provide certain conditions to take part in BIST 100 index. For example, top 100 firms having the highest market value and trading volumes are located in the index. This situation explains that the firms listed on BIST 100 index have higher market value than those which are not listed.

According to another finding, it has been determined positive relationship between external financing needs and firm value and has been not supported hypothesis 2 . In other words, it has been found when external financing needs increase (decrease) firm value increase (decrease). By contrast with, many scholars (Hennessy \& Whited, 2005; Lewellen \& Lewellen, 2006; Strebulaev, 2007; Almeida \& Campello, 2010) found negative relationship between external financing needs and firm value in their studies.

Almeida and Campello (2010) argue that the negative relationship is based on firms prefer less external financing appertaining to high profitability of firms. Since these firms comply with Pecking Order Theory, there was a negative relationship between external financing needs and firm value.

The firms in Turkey are resorting to more external financing since their profits are low (EBIT 4.7\%). In addition, since there is not have an effective long-term borrowing market in Turkey, firms prefer short-term borrowing (Short Term Financial Loans and Short Term Business Loans) for their financing needs. Therefore, the fact that short-term borrowing cost is lower than long-term borrowing leads to a positive relationship between external financing need and firm value. Almeida and Wolfenzon (2005), in agreement with this analysis, suggested that the use of external financing increased the value of the firm. Similarly, Chen et al. (2010) found that the need for external financing had a positive impact on firm value by increasing the quality of corporate governance practices.

It was determined that the relationship between leverage which is another independent variable and firm value was positive and Hypothesis 3 was not supported. This shows that as the financial leverage ratio of a firm increases, the value of the firm increases. In Turkey, firms benefit from short-term loans with lower borrowing costs and risks to meet their financing needs

It was determined that the relationship between the firm value and leverage, which is another independent variable of the study, was positive and Hypothesis 3 was not supported. This indicates that as a firm's financial leverage ratio increases, firm value will increase. Firms in Turkey benefit from short-term loans with lower borrowing costs and risks to meet their financing needs. The lower cost of the loans used and the lower risk are causing the relationship between leverage and firm value to be positive. Moreover, the lack of agency costs among lenders and shareholders due to the inefficient long-term borrowing market in Turkey explains that this relationship is positive. Demirgüç-Kunt and Maksimovic (1996) also found that there is a positive relationship between the development of banks and leverage. In contrast to this study, Jensen and Meckling (1976), Cohen and Lys (2006), Kasseeah (2008), Chen (2004) and Huang and Song (2006) found that there is a negative relationship between leverage and stock market value and profitability.

As in other independent variables, firm size positively influenced firm value and Hypothesis 4 was supported. This indicates that firms with large total assets in Turkey have a higher value than those with small total assets and that as the total assets of companies increase, firm values also increase. Singh and Whittington (1975), Glancey (1998) and Rashid (2014) found a significant positive relationship between firm size and performance. However, there are studies that find different results. For example, Jang and Park (2011) suggested that there is a negative relationship between firm size and firm value.

It is found that there is a positive relationship between firm value and operating profit margin added the model for representation of firm profitability and thus, hypothesis 5 is supported. This result similar to results of studies by Coad (2007), Asimakopoulous et al. (2009), Kouser et al. (2012) ve Rashid (2014). This finding obtained for Turkey supports common results in literature. Namely, the higher profitability of the firms has also been found to increase the firm value (It has been found that the firm value increase higher profitability of the firms). Since The firms which increase profitability use to available resources for financing of new investments, outsourcing rate of these firms decrease and this situation effect positively firm value. 


\section{Conclusion}

In the study, the effect of the need for external financing on the value of manufacturing firms was estimated with both static and dynamic panel data analysis approaches.

It was found that the manufacturing firms in Turkey have high growth potential and they are developing companies and that they have a high financial risk because they borrow more than half of their financing resources. Moreover, it was determined that the firms had a profit in terms of the main activity in the related periods though it was low level.

According to the correlations between the variables, it is seen that the firm value and the leverage ratio move parallel to each other whereas the firm value and the size move in the opposite direction. It was also found that firms with high values have a higher leverage ratio but smaller total assets. When the relationship between profitability, leverage and size is examined, there is a positive relationship between profitability and size, but a negative relationship between leverage and size and profitability. This finding suggests that larger firms have higher profitability and use less debt resources.

A period delay of the dependent variable on the firm value and the effect of the entire independent variables are positive and statistically significant. This finding indicates that previous period the firm value, taking place in the BIST 100 index, the need for external financing, the financial leverage ratio, the firm size and the profitability of the firm has increased firm value.

According to the results of the analysis, it is determined that firms in the BIST 100 index in Turkey have a higher firm value than firms that do not have the BIST 100 index. Moreover, since there is no effective long-term borrowing market in Turkey, it has been found that firms prefer short-term borrowing with lower risk and cost for financing needs. Thus, it has been determined that the external financing need and the leverage influence the firm value positively. In addition, as the asset totals and profitability of the firms increase, the firm values are also increased.

In the next stage, the corporate governance index based on the recent history in Turkey will be included in the next study and the effect of corporate governance and foreign financing needs on firm value will be examined.

\section{References}

Almeida, H., \& Campello, M. (2010). Financing Frictions and The Substitution Between Internal and External Funds, Journal of Financial and Quantitative Analysis, 45(3), 589-622. https://doi.org/10.1017/S0022109010000177

Almeida, H., \& Wolfenzon, D. (2005). The Effect of External Finance on The Equilibrium Allocation of Capital. Journal of Financial Economics, 75, 133-164. https://doi.org/10.1016/j.jfineco.2004.06.001

Anderson, R. C., Mansi, S. A., \& Reeb D. M. (2004). Board Characteristic, Accounting Report Integrity, and the Cost of Debt. Journal of Accounting and Economics, 37, 315-342. http://dx.doi.org/10.1016/j.jacceco.2004.01.004

Anderson, T. W., \& Hsiao, C. (1981). Estimation of Dynamic Models with Error Components. Journal of the American Statistical Association, 76, 375, 598-606. http://dx.doi.org/10.2307/2287517

Anderson, T. W., \& Hsiao, C. (1982). Formulation and Estimation of Dynamic Models Using Panel Data. Journal of Econometrics, 18, 47-82. https://doi.org/10.1016/0304-4076(82)90095-1

Arellano, M. (2003). Panel Data Econometrics. England: Oxford University Press.

Arellano, M., \& Bond, S. (1991). Some Tests of Specification for Panel: Monte Carlo Evidence and An Application to Employment Equations. Review of Economic Studies, 58, 277-297. https://doi.org/10.2307/2297968

Arellano, M., \& Bover, O. (1995). Another Look at the Instrumental Variable Estimation of Error-Components Models. Journal of Econometrics, 68, 29-51. https://doi.org/10.1016/0304-4076(94)01642-D

Asimakopoulous, I., Samitas, A., \& Papadogonas, T. (2009). Firm-specific and economy wide determinants of firm profitability Greek Evidence Using Panel Data. Managerial Finance, 35(11), 930-939. http://dx.doi.org/10.1108/03074350910993818

Baltagi, B. H. (2005). Econometric Analysis of Panel Data (3rd ed.). England: John Wiley \& Sons, Ltd.

Baltagi, B. H., \& Wu P. X. (1999). Unequally Spaced Panel Data Regressions with AR(1) Disturbances. Econometric Theory, 15, 814-823. 
Blundell, R., \& Bond, S. (1998). Initial Conditions and Moment Restrictions in Dynamic Panel Data Models. Journal of Econometrics, 87, 115-143. http://dx.doi.org/10.1016/S0304-4076(98)00009-8

Blundell, R., \& Bond, S. (2000). GMM Estimation with Persistent Panel Data: An Application to Production Functions. Econometric Reviews, 19, 321-340. http://dx.medra.org/10.1920/wp.ifs.1999.9904

Bond, S. (2002). Dynamic Panel Data Models: A Guide to Micro Data Methods and Practice. CEMMAP Working Paper, No: Cwp0209, 1-36.

Brown, M. B., \& Forsythe, A. B. (1974). The Small Sample Behavior of Some Statistics Which Test the Equality of Several Means. Technometrics, 16, 129-132. http://dx.doi.org/10.2307/1267501

Chen, W. P., Chung, H., Hsu, T. L., \& Wu, S. (2010). External Financing Needs, Corporate Governance and Firm Value. Corporate Governance: An International Review, 18(3), 234-249. http://dx.doi.org/10.1111/j.1467-8683.2010.00801.x

Coad, A. (2007). Testing the Principle of 'Growth of the Fitter': The Relationship Between Profits and Firm Growth. Structural $\quad$ Change and Economic Dynamics, 18(3), 370-386. http://dx.doi.org/10.1016/j.strueco.2007.05.001

Cohen, D., \& Lys, T. (2006). Weighing the Evidence on the Relation Between External Corporate Financing Activities, Accruals and Stock Returns. Journal of Accounting and Economics, 42(1-2), 87-105. http://dx.doi.org/10.1016/j.jacceco.2006.04.006

Demirgüç-Kunt, A., \& Maksimovic, V. (1998). Law, Finance and Firm Growth, Journal of Finance, 53(6), 2107-2137.

Ghosh, S. (2008). Leverage, Foreign Borrowing and Corporate Performance: Firm-Level Evidence For India. Applied Economics Letters, 15(8), 607-616. http://dx.doi.org/10.1080/13504850600722047

Glancey, K. (1998). Determinants of Growth and Profitability In Small Entrepreneurial Firms. International Journal of Entrepreneurial Behavior and Research, 4(1), 18-27. http://dx.doi.org/10.1108/13552559810203948

Greene, W. H. (2003). Econometric Analysis (50ty ed.). New Jersey: Prentice Hall.

Hausman, J. A. (1978). Specification Tests in Econometrics. Econometrica, 46, 1251-1271.

Higgins, R. C. (1977). How Much Growth Can a Firm Afford? Financial Management, 6(3), 7-16.

Hsiao, C. (2003). Analysis of Panel Data (2nd ed.). United Kingdom: Cambridge University Press.

Hughes, J., Liu, J., \& Liu, J. (2009). On The Relation Between Expected Returns and Implied Cost of Capital. Review of Accounting Studies, 14, 246-259. http://dx.doi.org/10.1007/s11142-009-9093-8

Jang, S., \& Park, K. (2011). Inter-relationship Between Firm Growth and Profitability. International Journal of Hospitality Management, 30(4), 1027-1035. http://dx.doi.org/10.1016/j.ijhm.2011.03.009

Kouser, R., Bano, T., Azeem, M., \& Hassan, M. (2012). Inter-Relationship Between Profitability, Growth and Size: A Case of Non-Financial Companies from Pakistan. Pakistan Journal of Commerce Social Sciences, 6(2), 405-419. http://dx.doi.org/10.17261/Pressacademia.2015424534

Langberg, N. (2008). Optimal Financing for Growth Firms. Journal of Financial Intermediation, 17, 379-406. http://dx.doi.org/10.1016/j.jfi.2008.02.001

Mckenon, J. J. (1969). Structure of Corporate External Financing. Financial Analysts Journal, September-October, 25-28.

Morck, R., \& Yang, F. (2001). The Mysterious Growing Value of S\&P 500 Membership. NBER Working Paper Series, No. 8654, 1-48. http://dx.doi.org/10.3386/w8654

Nissim, D., \& Penman, S. H. (2003). Financial Statement Analysis of Leverage and How It Informs About Profitability and Price to Book Ratios. Review of Accounting Studies, 8, 531-560. http://dx.doi.org/10.1023/A:1027324317663

Öztürk, E. (2001). Parametrik Olmayan ve Parametrik Panel Veri Modelleri: Çevresel Kuznets Eğrisinin Analizi. Marmara Üniversitesi SBE, Basılmamış Doktora Tezi.

Papadogonas, T. (2005). The Financial Performance of Large and Small Firms: Evidence From Greece. International Journal of Financial Services Management, 2(1), 14-20. http://dx.doi.org/10.1504/IJFSM.2007.011668 
Pesaran, M. H. (2004). General Diagnostic Tests for Cross Section Dependence in Panels. University of Cambridge, Faculty of Economics, Cambridge Working Papers in Economics No: 0435. https://doi.org/10.17863/CAM.5113

Platt, H. D., Platt, M. B., \& Chen, G. (1995). Sustainable Growth Rate of Firms in Financial Distress. Journal of Economics and Finance, 9(2), 147-151. http://dx.doi.org/10.1007/BF02920515

Singh, A., \& Whittington, G. (1975). The Size and Growth of Firms. Review of Economic Studies, 42(1), $15-26$.

Swamy, P. A. V. B., \& Mehta, J. S. (1977). Estimation of Linear Models With Time and Cross Sectionally Varying Coefficients. Journal of The American Statistical Association, 72, 360, 890-898.

White, H. (1980). A Heteroskedasticity-Consistent Covariance Matrix Estimator and A Direct Test for Heteroskedasticity. Econometrica, 48, 817-838. http://dx.doi.org/10.2307/1912934

Windmeijer, F. (2005). A Finite Sample Correction for The Variance of Linear Efficient Two-Step GMM Estimator. Journal of Econometrics, 126(1), 25-51. http://dx.doi.org/10.1016/j.jeconom.2004.02.005

Wooldridge, J. M. (2002). Econometric Analysis of Cross Section and Panel Data. England: The MIT Press.

\section{Copyrights}

Copyright for this article is retained by the author(s), with first publication rights granted to the journal.

This is an open-access article distributed under the terms and conditions of the Creative Commons Attribution license (http://creativecommons.org/licenses/by/4.0/). 